\title{
Saccharomyces cerevisiae Fermentation Effects on Pollen: Archaeological Implications
}

\author{
Crystal A. Dozier ${ }^{1 *}$ \\ ${ }^{1}$ Department of Anthropology, Texas A\&M University, College Station, USA. \\ *cdozier@tamu.edu
}

\begin{abstract}
Pollen is the reproductive agent of flowering plants; palynology is utilized by archaeologists because sporopollenin, a major component in the exine of pollen grains, is resistant to decay and morphologically distinctive. Wine, beer, and mead have been identified in the archaeological record by palynological assessment due to indicator species or due to a pollen profile similar to that recovered from honey, a common source of sugar in a variety of fermented beverages. While most palynologists have assumed that pollen grains are resistant to alcoholic fermentation, a recent study in food science implies that pollen is a yeast nutrient because pollen-enriched meads produce more alcohol. The experiment presented here explores the potential distortion of the pollen record through fermentation by brewing a traditional, pollen rich mead with Saccharomyces cerevisiae. In this experiment, the pollen grains did not undergo any discernible morphological changes nor were distorted in the pollen profile. Any nutrition that the yeast garners from the pollen therefore leaves sporopollenin intact. These results support palynological research on residues of alcoholic beverages and confirms that the fermentation process does not distort the pollen profile of the original substance. The paper concludes with the potential and limits of palynological study to assess fermentation within the archaeological record.
\end{abstract}

Received December 24, 2015

OPENठ ACCESS

Accepted March 9, 2016

DOI 10.14237/ebl.7.1.2016.573

Keywords Archaeological palynology, Fermentation, Mead, Fermented beverages, Melissopalynology

Supplementary Files available at ojs.ethnobiology.org/index.php/ebl/rt/suppFiles/573/290

Copyright (C) 2016 Dozier; licensee Society of Ethnobiology. This is an open-access article distributed under the terms of the Creative Commons AttributionNonCommercial 4.0 International Public License (https://creativecommons.org/licenses/by-nc/4.0), which permits non-commercial use, distribution, and reproduction in any medium, provided the original author and source are credited.

\section{Introduction}

A recent food science paper (Roldán et al. 2011) found that the addition of pollen while brewing mead resulted in higher alcohol content, as well as an improvement in taste. The authors conclude that pollen acts as a nutrient for Saccharomyces cerevisiae, the most common brewing yeast. While palynologists have long understood that ethanol does not alter the structure of pollen grains (pollen is often stored in ethanol), no direct study has looked at how $S$. cerevisiae metabolism affects pollen grains. A variety of bacteria and fungi are known to obliterate pollen from soil samples (Goldstein 1960; Havinga 1967). If brewing yeast consumes or alters the pollen in fermented beverages, prior arguments built on palynological assessments of fermented beverages may be unfounded. The research presented here observed pollen grains through the fermentation process to see if yeast metabolism altered the sporopollenin of individual grains or the pollen profile of honey as fermented into mead, beer, or wine.

Fermented Honey Beverages in the Archaeological Record

The development of fermented beverages in prehistory is of particular interest to archaeologists worldwide, as these technologies are associated with feasting societies, increasing social complexity, domestication of cereals, and the intensification of ceramic technocomplexes (Braidwood et al. 1953; Hayden 2009; Hayden et al. 2013; Smalley and Blake 2003). Honey is a prized commodity in many cultures and is a common source of sugar in a variety of fermented beverages, such as beer, wine, and mead. Humans have been exploiting the byproducts of honeybees (Apis mellifera) for at least the past 8500 years (Roffet Salque et al. 2015). Both beeswax and honey are incredibly useful bee products; honey is particularly 
important as one of the few sources of simple sugars available without processing. Hayden et al. (2013:108109) convincingly argue that the yeasts required for early fermentation probably originated either in honey or on acorn shells. Many early fermented beverages included at least some honey to increase the available sugars for yeast (and thereby increase alcohol content), perhaps to inoculate (introduce the yeast or fermenting microorganism) the beverage, and undoubtedly for taste (McGovem et al. 2003).

The consumption of alcoholic beverages is interpreted from the archaeological record when indicator pollen species are found in ceramic residues and within coprolites (Moe and Oeggl 2014). Vitis vinifera (grape) pollen has been used as a marker to distinguish wine amphorae from other storage vessels in Mediterranean shipwrecks (Arobba et al. 2014; Gorham and Bryant 2001; Jacobsen and Bryant 1998). High concentrations of Filipendula ulmaria (meadowsweet) pollen in coprolites has been interpreted as alcohol consumption as the plant is historically known to have been used as a flavoring agent in mead production (Moe and Oeggl 2014). The presence of cereal pollen has also been used to interpret ale and mead production (Lagerås 2000). This interpretive framework of looking for an indicator species only allows for confirmation of previously understood fermentation processes. Honey contains an extremely high concentration (and often diversity) of pollen grains, some of which are only commensal species-pollinated taxa. Diversity of commensal species-pollinated pollen has been used to identify honey and mead (Kvavadze et al. 2006; Rösch 1999).

Extensive review by Guerra-Doce (2014) indicates that a number of researchers in Europe have exploited palynology, the study of pollen grains, to identify potentially fermented beverages. She highlights studies that utilize palynology to identify mead and beer (see Supplementary File 1). No studies in North or South America have taken this approach; Apix honey bees were only introduced after the
Columbian exchange (Whitfield et al. 2006), although stingless bees (Meliponini) were exploited by the Maya for honey in the creation of a mead called balché (Bruman 2000:91-93).

\section{Melissopalynology}

Melissopalynology describes pollen found within honey (Jones and Bryant 1992, 1996; Low et al. 1989; Todd and Vansell 1942). Pollen is the reproductive agent of flowering plants; pollen grains have a wall containing sporopollenin that protects gametophytes during fertilization in spermatophytes. Angiosperms and gymnosperms use pollen to distribute genetic material between individuals, which aids in genetic diversity and the ability for a species to adapt to changing conditions. Luckily for archaeologists, sporopollenin is resistant to destruction over time and pollen grains can often be identified to species with use of light microscopy and computer-aided microscopy, such as SEM. Pollen is sequestered in/on plant reproductive organs (including fruits), sometimes released airborne, and carried by commensal species. Pollen does seem to provide some kind of nutritional value to brewing yeasts (Roldán et al. 2011).

\section{Methods}

In order to assess the effect that fermentation had on a pollen profile, I brewed a simple mead (honey wine) and tracked pollen profile and morphological integrity through the fermentation process.

Mead

As shown in Table 1, the only ingredients used in this mead were water, honey, yeast, and pollen pellets. Industrial honeys, such as was used in this experiment, are commonly micro-filtered to remove pollen and other particles-a misconception in the industry maintains that pollen can engender crystallization (Bryant 2014a). Therefore, pollen pellets were added in proportions close to Roldán et al. (2011)'s methods to ensure the presence of pollen in the mead. The pollen pellets contained a variety of common North American taxa with a variety of sizes and morphological traits.

Table 1 Materials used to make mead in this study.

\begin{tabular}{lll}
\hline Material & Amount & Source \\
\hline Water & $10 \mathrm{I}$ & Fort Worth, TX Municipal Water \\
Honey & $2512 \mathrm{~g}$ & Fermentap, Concord CA \\
Pollen Pellets & $192 \mathrm{~g}$ & The Wealth Savings Center, Valley Stream NY \\
Dry Yeast (S. cerevisiae) & $2 \mathrm{~g}$ & Lalvin Bourgovin RC212, Denmark \\
\hline
\end{tabular}


The honey and water were brought to a sanitizing threshold of $71{ }^{\circ} \mathrm{C}$ to create the must (the preinoculated substrate). The must was then cooled and the pollen pellets added and mixed thoroughly. The must was inoculated with $S$. cerevisiae yeast and left to ferment in a sealed, food grade plastic tub for seven days at $22-28{ }^{\circ} \mathrm{C}$. The specific gravity of the mead dropped from original gravity of 1.081 to a final gravity of 1.007; therefore, the resulting mead obtained approximately $9.71-10.50 \%$ alcohol by volume, consistent with mead characteristics. The mead finished with a Standard Reference Method (SRM) color of 15, a rich golden light brown.

\section{Pollen Sampling}

Several samples of the mead were taken through the brewing process to track the pollen profile. Two 50 $\mathrm{mL}$ samples were taken before inoculation (referred to as must) and two more $50 \mathrm{~mL}$ samples were taken after fermentation had completed (referred to as mead). The must/mead was stirred well before sampling to ensure no settling of pollen out of the samples. The four samples were frozen before analysis at the Texas A\&M Palynological Research Laboratory.

\section{Pollen Analysis}

Samples were analyzed adopting standard melissopalynological procedures (Jones and Bryant 1996) at the Texas A\&M Palynological Research Laboratory. Ten $\mathrm{mL}$ subsamples were taken from each of the mead/ must samples, to which one lycopodium tablet (18583 spores/tab) was added. The water source for the $\mathrm{mead} / \mathrm{must}$ was not tested for pollen as pollen was intentionally added to the must; however, all equipment within the Texas A\&M Palynological Research Laboratory is regularly tested for pollen contamination and the Laboratory distilled water is pollen-free, so no pollen was added subsequent to fermentation. The samples were then centrifuged at $3500 \mathrm{rpm}$ for two minutes, the same time and speed for all of the subsequent washes. The supernatant liquid was decanted and the samples were washed with $7 \mathrm{~mL}$ of glacial acetic acid. A standard acetolysis regime was followed whereas $7 \mathrm{~mL}$ of a 1:9 ratio of sulfuric acid to acetic anhydride was added to each sample and heated for 10 minutes at $80{ }^{\circ} \mathrm{C}$. The samples were stirred occasionally before being washed with $7 \mathrm{~mL}$ of glacial acetic acid. The samples were then washed in water and ethanol (Jones and Bryant 2004) before seven drops glycerin were added per sample and the samples were mounted to a slide.

One slide from each sample was analyzed under light microscopy. At least 200 grains were analyzed from each sample, as is standard practice and statistically secure (Barkley 1934). Broad identifications were made to assign pollen grains to taxonomic family or genera, but exact identifications were irrelevant. Rather, the relative frequency of different pollen types was the most important facet to understand if and how the yeast used the pollen as a nutrient. Supplemental Data File 2 contains the raw counts of taxa and their relative frequencies.

\section{Results}

Pollen preservation in the must and mead samples was phenomenal and no damage to pollen walls was observed under light microscopy. Figure 1 indicates the diversity of pollen taxa recovered. Figure 2 illustrates the relative frequencies of the different pollen types; no significant differences in the pollen profiles of any of the samples were observed following fermentation.
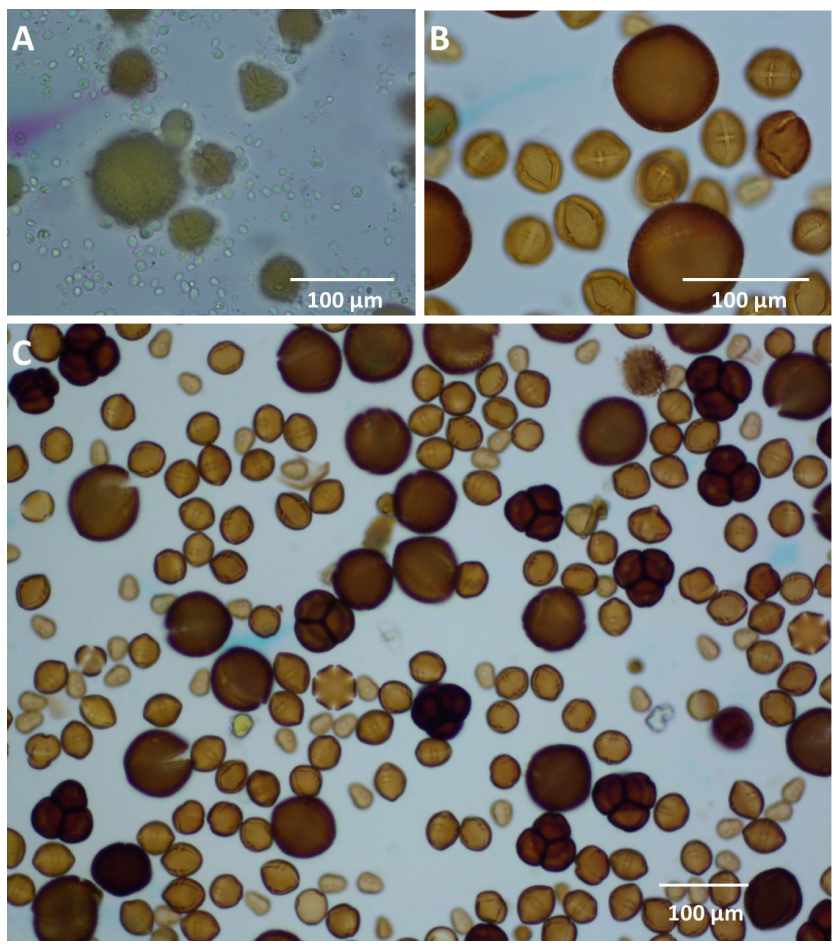

Figure $1 \mathrm{~A}$ Mead sample prior to processing. Note presence of yeast cells around pollen grains. B \& C Mead sample after acetolysis. No damage to pollen exines. Note pollen and spore diversity. 


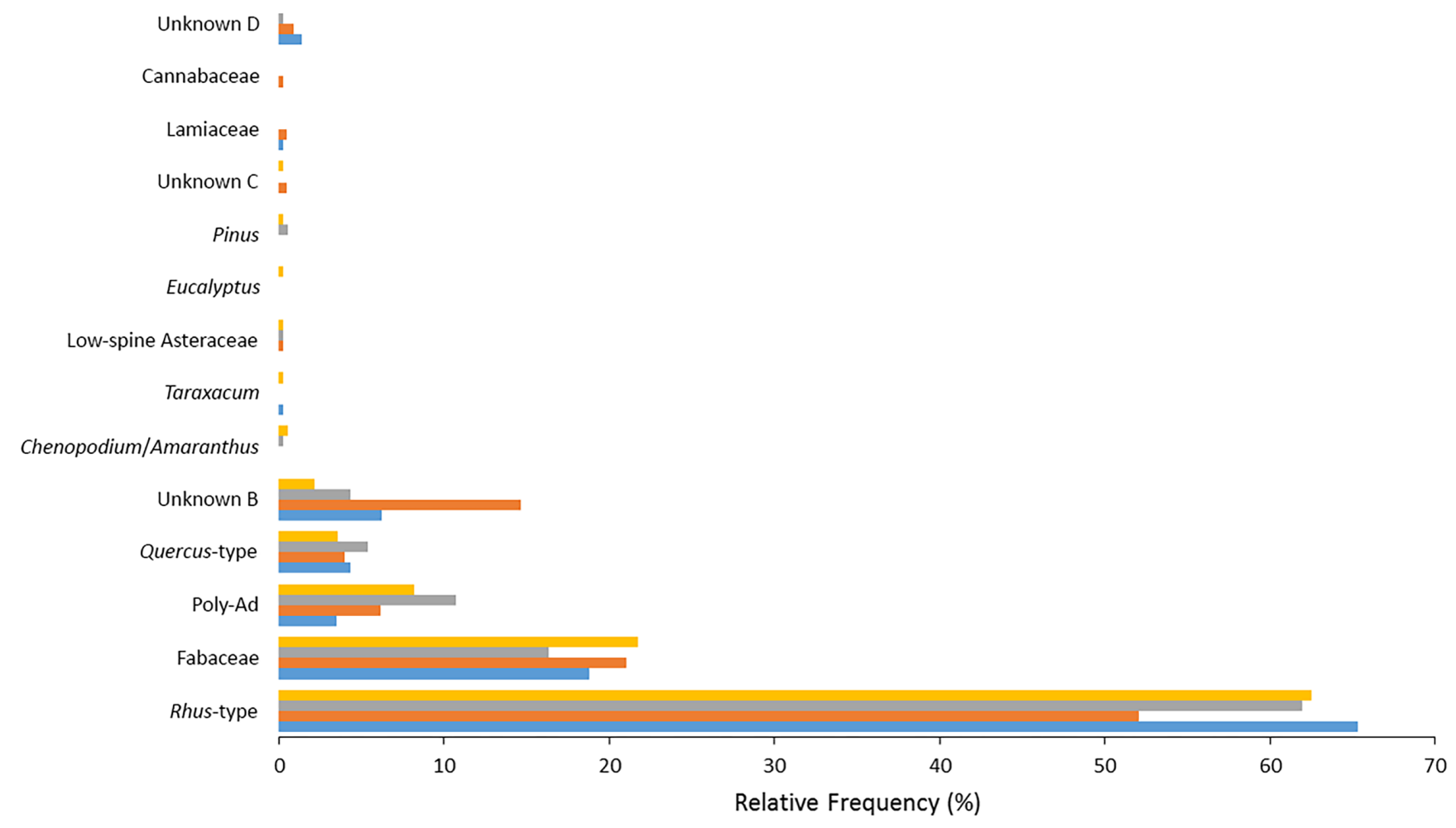

Figure 2 Relative frequencies of pollen types. No significant differences in pollen type frequency are seen among the four samples.

\section{Discussion}

While Roldán et al. (2011) found the addition of pollen increased lipids and other nutrients for $S$. cerevisiae that resulted in higher ethanol production (indicating yeast metabolism of pollen grains), the individual exines of pollen grains and pollen profile of honey remained unchanged under light microscopy through fermentation. Any nutrition that the yeast garners from the pollen therefore leaves sporopollenin intact; differentiation between unaltered and fermented food residues based on palynological analysis alone is unlikely. It is possible that minor damage to sporopollenin may be visible under scanning electron microscopy (SEM). This study did not have the resources to pursue this possibility, which may be an avenue for future research.

The research presented here supports interpretations of honey in archaeological residues through palynological analysis (Kvavadze et al. 2006; Lagerås 2000; Moe and Oeggl 2014; Rösch 1999). As always, though, archaeologists and paleo(ethno)botanists need to remain cognizant of other taphonomic processes (Bryant and Hall 1993; Cushing 1967; Havinga 1967) that may affect the palynological record. For example, wetting and drying cycles are known to destroy pollen grains (Campbell and Campbell 1994). With secure context and proper control sampling, however, palynological analysis of possibly fermented residues have the potential of greatly informing the archaeological record. Palynological assessments may provide additional paleoenvironmental insights beyond identifying honey utilization because pollen in honey profiles can reflect some aspects of local environments (Bryant 2014b; Kvavadze et al. 2006; Rösch 1999).

\section{Conclusions}

A simple mead (honey wine) was brewed to assess if pollen grains are affected by fermentation processes. Palynological analysis of both must (pre-fermentation) and mead (post-fermentation) indicates that no damage to the pollen exine occurs and there are no 
differences in the pollen profile through the brewing process. This study confirms that fermented beverages contain the same pollen profile as their unfermented bases, which supports previous interpretations of honey from archaeological residues (Kvavadze et al. 2006; Lagerås 2000; Moe and Oeggl 2014; Rösch 1999). This study implies that palynological analysis alone cannot differentiate between unaltered and fermented honey residues under light microscopy. However, pollen profiles of honey can indicate some aspects of the local environment (Bryant 2014b); therefore, palynological assessment of archaeological residues of foods made with honey may yield reliable paleoenvironmental data.

\section{Acknowledgements}

I would like to thank the Texas A\&M University Palynological Research Laboratory, and especially Dr. Vaughn Bryant Jr., for guidance and support through this project. Comments and suggestions from participants of the session "Exploring the production and consumption of fermented beverages and food in pre- and protohistoric communities" at the $21^{\text {st }}$ Annual Meeting of the European Association of Archaeologists improved this paper. I also appreciate the thoughtful comments and suggestions of two anonymous reviewers and the patience of Ethnobiology Letters' excellent editing staff.

\section{Declarations}

Permissions: V.M. Bryant, Jr. allowed for the use of the Palynological Research Laboratory at Texas A\&M University for this study.

Sources of Funding: This study was funded by the author.

Conflicts of Interest: None declared.

\section{References Cited}

Arobba, D., F. Bulgarelli, F. Camin, R. Caramiello, R. Larcher, and L. Martinelli. 2014. Palaeobotanical, Chemical and Physical Investigation of the Content of an Ancient Wine Amphora from the Northern

Tyrrhenian Sea in Italy. Journal of Archaeological Science 45:226-33.

Barkley, F. A. 1934. The Statistical Theory of Pollen Analysis. Ecology 15:283-89.

Braidwood, R. J., J. D. Sauer, H. Helbaek, P. C. Mangelsdorf, H. C. Cutler, C. S. Coon, R. Linton, J. Steward, and A. L. Oppenheim. 1953. Symposium:
Did Man Once Live by Beer Alone? American Anthropologist 55:515-526.

Bruman, H. J. 2000. Alcohol in Ancient Mexico. University of Utah Press, Salt Lake City, UT.

Bryant, V. M., Jr., and S. A. Hall. 1993. Archaeological Palynology in the United States: A Critique. American Antiquity 58:277-86. DOI:10.2307/281970.

Bryant, V. M., Jr. 2014a. The Basics of Honey Identification. Bee Culture April:59-63.

Bryant, V. M., Jr. 2014b. Truth in Labeling: Honey Testing. Bee Culture August:29-33.

Campbell, I. D., and C. Campbell. 1994. Pollen Preservation: Experimental Wet-Dry Cycles in Saline and Desalinated Sediments. Palynology 18:510. DOI:10.2307/3687753.

Cushing, E. J. 1967. Evidence for Differential Pollen Preservation in Late Quaternary Sediments in Minnesota. Review of Palaeobotany and Palynology 4:87101. DOI:10.1016/0034-6667(67)90175-3.

Goldstein, S. 1960. Degradation of Pollen by Phycomycetes. Ecology 41:543-45. DOI:10.2307/1933329.

Gorham, L. D., and V. M. Bryant, Jr. 2001. Pollen, Phytoliths, and Other Microscopic Plant Remains in Underwater Archaeology. International Journal of Nautical Archaeology 30:282-98.

Guerra-Doce, E. 2014. The Origins of Inebriation: Archaeological Evidence of the Consumption of Fermented Beverages and Drugs in Prehistoric Eurasia. Journal of Archaeological Method and Theory 22:751-782. DOI:10.1007/s10816-014-9205-z.

Havinga, A. J. 1967. Palynology and Pollen Preservation. Review of Palaeobotany and Palynology 2:81-98. DOI:10.1016/0034-6667(67)90138-8.

Hayden, B. 2009. The Proof Is in the Pudding. Current Anthropology 50:597-601.

Hayden, B., N. Canuel, and J. Shanse. 2013. What Was Brewing in the Natufian? An Archaeological Assessment of Brewing Technology in the Epipaleolithic. Journal of Archaeological Method \& Theory 20:102-150.

Jacobsen, M., and V. M. Bryant, Jr. 1998. Preliminary Fossil Pollen Analysis of Terebinth Resin from a 15Century BC Shipwreck at Ulu Burun, Turkey. In New Developments in Palynomorph Sampling, Extraction, and Analysis, edited by V. M. Bryant, Jr. and J. 
Wrenn, pp. 75-82. Contributions Series-American Association of Stratigraphic Palynologists. American Association of Stratigraphic Palynologists Foundation, Dallas, TX.

Jones, G. D., and V. M. Bryant, Jr. 1996. New Frontiers in Palynology. In Palynology: Principles and Applications, edited by J. Jansonius and D.C. McGregor, pp. 933-38. American Association of Stratigraphic Palynologists Foundation, Dallas, TX.

Jones, G. D., and V. M. Bryant, Jr. 2004. The Use of ETOH for the Dilution of Honey. Grana 43:17482.

Jones, G. D., and V. M. Bryant, Jr. 1992. Melissopalynology in the United States: A Review and Critique. Palynology 16:63-71.

DOI:10.1080/01916122.1992.9989407.

Kvavadze, E., I. Gambashidze, G. Mindiashvili, and G. Gogochuri. 2006. The First Find in Southem Georgia of Fossil Honey from the Bronze Age, Based on Palynological Data. Vegetation History and Archaeobotany 16:399-404. DOI:10.1007/s00334-006 -0067-5.

Lagerås, P. 2000. Burial Rituals Inferred from Palynological Evidence: Results from a Late Neolithic Stone Cist in Southem Sweden. Vegetation History and Archaeobotany 9:169-73.

Low, N. H., C. Schweger, and P. Spoms. 1989. Precautions in the Use of Melissopalynology. Journal of Apiculture Research 28:50-54.

McGovern, P. E., S. J. Fleming, and S. H. Katz. 2003. The Origins and Ancient History of Wine: Food and Nutrition in History and Anthropology. Routledge, New York, NY.

Moe, D., and K. Oeggl. 2014. Palynological Evidence of Mead: A Prehistoric Drink Dating Back to the 3rd Millennium B.C. Vegetation History and Archaeobotany 23:515-26. DOI:10.1007/s00334-013-0419-x.

Roffet-Salque, M., M. Regert, R. P. Evershed, A. K. Outram, L. J. E. Cramp, O. Decavallas, J. Dunne, P. Gerbault, S. Mileto, S. Mirabaud, M. Pääkönen, J. Smyth, L. Šoberl, H. L. Whelton, A. Alday-Ruiz,
H. Asplund, M. Bartkowiak, E. Bayer-Niemeier, L. Belhouchet, F. Bernardini, M. Budja, G. Cooney, M. Cubas, E. M. Danaher, M. Diniz, L. Domboróczki, C. Fabbri, J. E. González-Urquijo, J. Guilaine, S. Hachi, B. N. Hartwell, D. Hofmann, I. Hohle, J. J. Ibáñez, N. Karul, F. Kherbouche, J. Kiely, K. Kotsakis, F. Lueth, J. P. Mallory, C. Manen, A. Marciniak, B. Maurice-Chabard, M. A. Mc Gonigle, S. Mulazzani, M. Özdoğan, O. S. Perić, S. R. Perić, J. Petrasch, A. Pétrequin, P. Pétrequin, U. Poensgen, C. J. Pollard, F. Poplin, G. Radi, P. Stadler, H. Stäuble, N. Tasić, D. Urem-Kotsou, J. B. Vuković, F. Walsh, A. Whittle, S. Wolfram, L. Zapata-Peña, and J. Zoughlami. 2015. Widespread Exploitation of the Honeybee by Early Neolithic Farmers. Nature 527:226-30. DOI:10.1038/nature15757.

Roldán, A., G. C. J. van Muiswinkel, C. Lasanta, V. Palacios, and I. Caro. 2011. Influence of Pollen Addition on Mead Elaboration: Physicochemical and Sensory Characteris tics. Food Chemistry 126:57482. DOI:10.1016/j.foodchem.2010.11.045.

Rösch, M. 1999. Evaluation of Honey Residues from Iron Age Hill-Top Sites in Southwestem Germany: Implications for Local and Regional Land Use and Vegetation Dynamics. Vegetation History and Archaeobotany 8:105-12. DOI:10.1007/BF02042848.

Smalley, J., and M. Blake. 2003. Sweet Beginnings. Current Anthropology 44:675-703.

Todd, F. E., and G. D. Vansell. 1942. Pollen Grains in Nectar and Honey. Journal of Economic Entomology 35:728-31.

Whitfield, C. W., S. K. Behura, S. H. Berlocher, A. G. Clark, J. S. Johnston, W. S. Sheppard, D. R. Smith, A. V. Suarez, D. Weaver, and N. D. Tsutsui. 2006. Thrice Out of Africa: Ancient and Recent Expansions of the Honey Bee, Apis Mellifera. Science 314:642-45. DOI:10.1126/science.1132772.

Supplementary Files are linked to the online version of the paper at ojs.ethnobiology.org/index.php/ebl/rt/ suppFiles/573/290. 